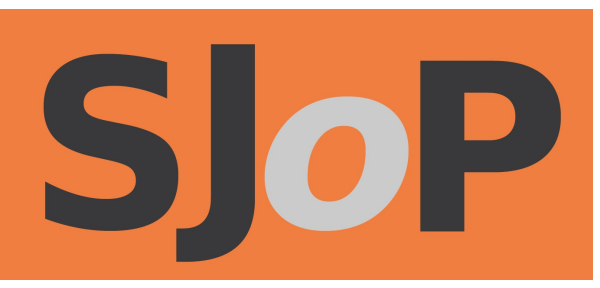

\title{
Symposium abstracts: The making of performance: stories of performing physicalities
}

\author{
ANDRIA CHRISTOFIDOU \& LITO TSITSOU, \\ ANNA BIRCH, SIMON MURRAY, BETHANY WHITESIDE, \\ LITO TSITSOU \& LUCY WEIR, RAMSAY BURT, \\ ROMANY DEAR \& DOMINIC PATERSON
}

Scottish Journal of Performance

Volume 1, Issue 1; December 2013

ISSN: 2054-1953 (Print) / ISSN: 2054-1961 (Online)

Publication details: http://www.scottishjournalofperformance.org

To cite this article: Christofidou, A. and Tsitsou, L., Birch, A., Murray, S., Whiteside, B., Tsitsou, L. and Weir, L., Burt, R., Dear, R. and Paterson, D., 2013. Symposium abstracts: The making of performance: stories of performing physicalities. Scottish Journal of Performance, 1(1), pp.99107.

To link to this article: http://dx.doi.org/10.14439/sjop.2013.0101.06

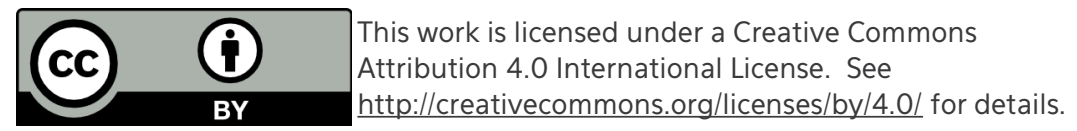




\section{The making of performance: stories of performing physicalities}

SYMPOSIUM ABSTRACTS:

ANDRIA CHRISTOFIDOU \& LITO TSITSOU, ANNA BIRCH, SIMON MURRAY, BETHANY WHITESIDE, LITO TSITSOU \& LUCY WEIR, RAMSAY BURT, ROMANY DEAR \& DOMINIC PATERSON

DOI: 10.14439/sjop.2013.0101.06

Publication date: 13 December 2013

The making of performance: stories of performing physicalities Saturday 22nd June 2013

Gilbert Scott Conference Suite Room, Main Building, University of Glasgow

Funded by The RLI Fund from the College of Social Sciences, University of Glasgow

The making of performance: stories of performing physicalities was a symposium organised by Andria Christofidou (PhD Candidate, Sociology, University of Glasgow) and Dr Lito Tsitsou (Teaching Assistant in Sociology and Research Methods and Research Assistant in the Strathclyde Centre for Disability, School of Social and Political Sciences, University of Glasgow) in an effort to establish a network of academics and practitioners with sociological interest in theatrical and/or physical performance in Scotland. As such, the event brought together people from different (academic) backgrounds and disciplines and engaged them in an interdisciplinary dialogue about social and sociological aspects of physical performance and experience, drawing on historical, theoretical and empirical material. The event, which took place on 22nd June 2013 at the University of Glasgow, comprised two parts: a series of presentations and discussions that looked at physical performance from both 
Scottish Journal of Performance

Volume 1, Issue 1

historical and empirical perspectives and a panel discussion on methodology in physical performance research.

The organisers invited eight speakers to discuss their work: Dr Anna Birch discussed the relationship between gender and archiving performance; Professor Ramsay Burt looked at black dance production in twentieth century Britain; Dr Simon Murray discussed the usefulness of Raymond William's concept 'structure of feeling' for Theatre Studies; Romany Dear and Dr Dominic Paterson presented a paper based on their shared experience of participating in Yvonne Rainer's workshop; Dr Lito Tsitsou and Dr Lucy Weir looked at Mary Wigman's work Hexentanz (I and II) as an Oriental piece that marked the making of modern dance more widely, and a modern dance that would later be considered 'German'; and finally, Bethany Whiteside discussed findings from her study on 'Scottishness' and Highland Dancing.

The second part of the symposium included a discussion of methodological issues emerging from the study of physical performance. Speakers and audience discussed issues such as ethical research practice, the validity of historical sources and dealing with source contradictions, the politics of performance, spectatorship and embodiment.

ANDRIA CHRISTOFIDOU \& DR LITO TSITSOU

\section{ANNA BIRCH}

\section{Not the final word...}

Drawing on current debates around what constitutes an archive and how performance can be understood as a feature of the archive itself, this short presentation will examine the role of the body as an archival artefact. Central issues of inclusion and exclusion in the archive and how 
selected archives can be re-activated and made accessible to a new audience will be discussed. Building on the work of Fragments \& Monuments-(founded in 1998 by myself and scenographer Madelon Schwirtz)-some strategies will be shared arising from my practice as research. Film and performance are employed as an iterative methodology to investigate physicality and gender in particular performance case studies and through a multimodal (Hodge and Kress 1988; van Leeuwen and Jewitt 2001; 2002) architecture spanning live performance, film, projection, broadcast, gallery installation and publication. A range of strategies for engaging with the performance archive have emerged; for example the projection of the live performance onto the site where the original performance took place one year later and uploading 'strips' of this video footage for performance research analysis (Birch 2004; 2006; 2007). This research will form the basis of a contribution that discusses in part how embodied vocabularies may be shown to develop a dialogue with texts that are generally ascribed more value.

DR ANNA BIRCH is Artistic Director and founder member of Fragments \& Monuments performance and film company and currently Lecturer, Research at the Royal Conservatoire of Scotland in Glasgow where she supervises a number of $\mathrm{PhD}$ students. As a practice-led researcher, publications include co-editing 'Sitespecificity and mobility', Contemporary Theatre Review, Vol. 22, Issue 2 (Routledge) and a collection entitled Performing Site-specific Theatre: Politics, Place, Practice which includes her latest essay 'Repetition and performativity: site-specific performance and film as living monument' (Palgrave, 2012) both with Professor Joanne Tompkins (University of Queensland, Australia).

\section{SIMON MURRAY}

\section{Physical theatres as cultural production: structures of feeling and other lenses}

One of the most notable features of contemporary Western theatre over the last three decades has been the ubiquity with which terms like 'physical', 'corporeal', 'visual' and 'embodied' have been claimed by, or ascribed to 
performance companies, individual artists and the work they make. Physical theatre, although hugely imprecise and unclear about what it seeks to describe, has become a badge to indicate distance from the typical naturalistic conventions of the 'well-made play' on the one hand, and to suggest a risky, visceral and sometimes virtuosic display of performing bodies on the other. This paper will offer some reflections on the rise and rise of so-called physical theatres as cultural production, and consider how we might productively try to position these various forms of theatre within a wider social and cultural context. Suggestion will be made that Raymond Williams' term 'structures of feeling' offers a generative lens-a way of seeing-for critically reflecting upon this upsurge in physical and dance theatres.

DR SIMON MURRAY currently teaches Theatre Studies at the University of Glasgow. Previously he was Director of Theatre at Dartington College of Arts in Devon up to the moment of its closure and subsequent merger with University College Falmouth in 2008, and before that a professional performer and theatre maker working largely in the fields of devised visual and physical theatre. He is a sociologist 'by trade' and spent much of the '70s and early '80s working in adult and trade union education. He has published on Jacques Lecoq, on physical theatres, on lightness and, most recently, on the writings of WG Sebald and their relationship to contemporary performance. With Jonathan Pitches he is co-founder and co-editor of the Routledge journal Theatre, Dance and Performance Training.

\section{BETHANY WHITESIDE}

\section{Dance then wherever you may be: perceptions of 'Scottishness' in Highland Dancing in Glasgow, Scotland}

Highland Dancing is viewed as a form of dance and sport, as a link to the romantic past of Highland history, and as part of a rigid competitive structure regulated by official boards and associations. Despite or perhaps because of these conflicting states, Highland Dancing may first and foremost be defined by its 'Scottishness', a conceptual myriad of cultural, social and political identities located nationally, regionally and locally (Bairner 2001). A key performance 
arena for Highland dancers is Highland Games, widely recognised as both a tourism and sporting event, and through its location within these arenas, Highland Dancing has become identified with a particular brand of nostalgic 'Scottishness'-that of the 'old country'-in Scotland and abroad. Relevant studies have tended to focus on Highland Games as a whole and on events taking place abroad (e.g. Chabbra et al., 2003; Ray, 2001). In this paper, I draw on interviews and observations of Highland dancers at a private dance studio in Glasgow. Using the 'thinking tools' of Pierre Bourdieu, I explore why these dancers want to do Highland Dancing; how notions of 'Scottishness' inform their individual and collective dispositions; and how participation in Highland Dancing builds different but related kinds of cultural, social and physical capital.

My analysis suggests that, while Highland Dancing may be a vehicle for sustaining Scottish culture across the diaspora, within Scotland itself, dancers are more concerned with the social and physical aspects of the dance.

Following completion of her BA Hons in History in 2005, BETHANY WHITESIDE worked for a number of arts organisations in an education, marketing and project management capacity. In 2009 she joined the MSc Dance Science and Education programme at the University of Edinburgh, and in 2011 embarked on an ESRC CASE Studentship, supported by Capacity Building Cluster 'Capitalising on Creativity' grant №RES 187-24-0014, focusing on the sociology of participatory dance.

Since embarking on her $\mathrm{PhD}$, Bethany has presented and published at national and international conferences and given guest lectures at the Royal Conservatoire of Scotland and the University of Edinburgh. She is also co-editor of the Scottish Journal of Performance.

\section{LITO TSITSOU \& LUCY WEIR}

\section{Hexentanz: ritualism and the making of early modern 'German' dance}

This paper will discuss Mary Wigman's Hexentanz

(including the original 1914 choreography as well as the 
better-known 1926 version), as a prominent example of a key social and aesthetic process manifested in dance in the first decades of the twentieth century; namely, the reversion to primitive forms as a means of devising a new, avant-garde creative practice. Freikörperkultur, the notion of naturistinspired free body culture, was widely practised throughout Germany and the former Austro-Hungarian Empire, and in this paper we will focus on the example of the liberal colony at Ascona, Switzerland as part of a generalised phenomenon of ritualistic body culture. The concept of returning to nature and simplified healthy living was seen as an antidote to rapid capitalist modernisation of the West, and Germany in particular.

Wigman developed her conception of dance within this context, and Hexentanz therefore represents the first materialisation of a return to archaic cultural practices in her choreographic oeuvre. As we shall demonstrate, Hexentanz II drew on various elements of non-Western cultures and rituals, which both demonise and valorise the Orientalist 'Other'. However, as these influences became systematised into dance practice and technique, they paved the way for new conceptions of dance and movement; in the end, it is elements of this Orientalist 'Other' that formulate the basis of early twentieth century modern dance and modern dance produced in Germany developed as distinctively German. The ritual practices of the 'Other' are seen as primordial and acquire moral and aesthetic significance. However, as Edward Said would argue, they are utilised for the benefit of the West and German modern dance in particular. Hexentanz II (1926), as a work of dance devised in the post-war period, was produced under conditions of social discontent and experiences of alienation very much nurtured since the pre-war period. The witch's dance, as the name suggests, indicates a return to the 'primitive' ritual, which as we shall see is also linked both with the non-Western 'Other' and non-Western ritualism. This paper will provide a re-reading of Wigman's cultural 
and ritualistic influences in devising a distinctly German, though Orientalist-inspired dance aesthetic.

DR LITO TSITSOU is a former dancer and currently a Researcher and a Teaching Assistant at the School of Social and Political Sciences at the University of Glasgow. She obtained her $\mathrm{PhD}$ from the University of Glasgow during which she examined the social and aesthetic conditions of possibility of Ballet and Contemporary Dance Production drawing on historical material from the West and on an empirical comparative investigation of dance in Greece and the UK. Lito focused on the class origins of dance practitioners, phenomena of institutional power and aesthetic tensions as interwoven in the politics of dance in different social contexts. Her current interests revolve around the making of the dancing body, disability and dance and the Social Theory of Pierre Bourdieu.

DR LUCY WEIR obtained her PhD in History of Art and Theatre Studies from the University of Glasgow. Specialising in modern dance and performance studies, her research interests include experimental theatre practices, Viennese Actionism, and Japanese postwar performance. Lucy regularly gives public talks on the History of Art and Dance, and lectures on a variety of subject areas within Art History and Dance Studies at the University of Glasgow and the Glasgow School of Art.

\section{RAMSAY BURT}

\section{Dance Britannia! Black British dancers and the African Diaspora}

The music and dance of African Diasporan artists has impacted upon current dance practice in Britain and their legacies are testament to the global circulation of artistic ideas. The migration of African Caribbean people to Britain in the 1940s and 1950s laid the foundation for a rich cultural tapestry which continues to influence British Dance today, yet is largely unrecognised. This paper discusses the British Dance and the African Diaspora research project which seeks to write Black British dance artists and their legacies back into history. It investigates the nexus of aesthetic, institutional and conceptual problems that have rendered these dancers invisible. A key factor, we believe, is the inadequacy of existing frameworks to provide a suitable basis for analysis. Drawing on concepts from Michel Foucault and Judith Butler and from post-colonial studies, 
the aim of this paper is to investigate the ways in which institutional power is invested within this sector. It does so by focusing on the links between critical discourse and the effects of administrative decisions made by funding bodies.

PROFESSOR RAMSAY BURT is Professor of Dance History at De Montfort University, UK. His publications include The Male Dancer (1995, revised 2007), Alien Bodies (1997), Judson Dance Theater (2006), and, with Valerie Briginshaw, Writing Dancing Together (2009). In 1999 he was Visiting Professor at the Department of Performance Studies, New York University, and he is a visiting teacher at PARTS in Brussels. With Susan Foster, Ramsay Burt is founder editor of Discourses in Dance. With Christy Adair, he has run the AHRC-funded research project into British Dance and the African Diaspora.

\section{ROMANY DEAR \& DOMINIC PATERSON}

\section{Rehearsing war and performing memory: a collaborative response to Yvonne Rainer's dance workshop}

Romany Dear and Dominic Paterson will present a collaborative response to their shared experience of participating in a dance workshop led by Yvonne Rainer in Glasgow in 2010. The workshop centred on the rehearsal of her 1970 work $W A R$, and this piece, along with the various iterations of Rainer's best-known dance work Trio $A$, is central to this presentation. Using Rainer's own performative lecture Where's the Passion? (2009) as a model for their reflections, Dear and Paterson explore the importance of repetitions, re-performances, de-framings and interruptions to the radical reworking of dance and its relationship to subjective expression. 
ROMANY DEAR is an artist who graduated from the Environmental Art course at Glasgow School of Art in 2011 and continues to work and live in Glasgow. She has recently exhibited in Dance is a Language That We Speak, Intermedia Gallery, CCA. Glasgow, 2013; Studio 58: Women Artists Since World War 2, Mackintosh Gallery, Glasgow, 2012; and as part of They Had Four Years, Generator Gallery, Dundee, 2012. Romany also co-founded the organisation Glasgow Open Dance School with Julia Scott in 2012.

DR DOMINIC PATERSON is a writer and Lecturer in History of Art at the University of Glasgow. He has written widely on contemporary art, including recent texts on Christine Borland, Martin Soto Climent, Kate Davis, Lucy Gunning, Alex Impey, Scott Myles, Jimmy Robert, and Stina Wirfelt (amongst others). In 2012 he participated in the group exhibitions Adaptation at Collective, Edinburgh; What We Have Done, What We Are About To Do, CCA, Glasgow, and Prawn's Pee, The Old Hairdresser's, Glasgow. 